\title{
Recent advances in cochlear hair cell nanophysiology: subcellular compartmentalization of electrical signaling in compact sensory cells
}

\author{
Thomas Effertz $^{1}$ Tobias Moser (iD) ${ }^{2-5^{*}}$ Dominik Oliver (iD) ${ }^{6-8^{*}}$ \\ ${ }^{1}$ InnerEarLab, Department of Otorhinolaryngology, University Medical Center Göttingen, 37099 Göttingen, Germany \\ ${ }^{2}$ Institute for Auditory Neuroscience and InnerEarLab, University Medical Center Göttingen, 37099 Göttingen, Germany \\ ${ }^{3}$ Auditory Neuroscience Group, Max Planck Institute for Experimental Medicine, 37075 Göttingen, Germany \\ ${ }^{4}$ Synaptic Nanophysiology Group, Max Planck Institute for Biophysical Chemistry, 37077 Göttingen, Germany \\ ${ }^{5}$ Multiscale Bioimaging Cluster of Excellence (MBExC), University of Göttingen, 37075 Göttingen, Germany \\ ${ }^{6}$ Institute for Physiology and Pathophysiology, Philipps University, Deutschhausstraße 2, 35037 Marburg, Germany \\ ${ }^{7}$ Center for Mind, Brain and Behavior (CMBB), Universities of Marburg and Giessen, Germany \\ ${ }^{8}$ DFG Research Training Group, Membrane Plasticity in Tissue Development and Remodelling, GRK 2213, Philipps University, Marburg, Germany
}

\begin{abstract}
In recent years, genetics, physiology, and structural biology have advanced into the molecular details of the sensory physiology of auditory hair cells. Inner hair cells (IHCs) and outer hair cells (OHCs) mediate two key functions: active amplification and nonlinear compression of cochlear vibrations by OHCs and sound encoding by IHCs at their afferent synapses with the spiral ganglion neurons. OHCs and IHCs share some molecular physiology, e.g. mechanotransduction at the apical hair bundles, ribbon-type presynaptic active zones, and ionic conductances in the basolateral membrane. Unique features enabling their specific function include prestin-based electromotility of $\mathrm{OHCs}$ and indefatigable transmitter release at the highest known rates by ribbon-type IHC active zones. Despite their compact morphology, the molecular machineries that either generate electrical signals or are driven by these signals are essentially all segregated into local subcellular structures. This review provides a brief account on recent insights into the molecular physiology of cochlear hair cells with a specific focus on organization into membrane domains.
\end{abstract}

\section{Keywords}

Auditory hair cell, Mechanoelectrical transduction, Ion channel clustering, Synaptic physiology, Nanodomain, Phosphoinositide, Potassium channel, Compartmentalization, Basolateral membrane, Prestin, TMC1, Cav1.3

\section{Peer Review}

The peer reviewers who approve this article are:

1. Jung-Bum Shin, Department of Neuroscience, University of Virginia, Charlottesville, VA, 22908, USA Competing interests: No competing interests were disclosed.

2. Régis Nouvian, Institut des Neurosciences de Montpellier (INM), Inserm, University of Montpellier, Montpellier, France Competing interests: No competing interests were disclosed. 
*Corresponding authors: Tobias Moser (tmoser@gwdg.de); Dominik Oliver (oliverd@staff.uni-marburg.de)

Competing interests: The authors declare that they have no competing interests.

Grant information: Tobias Moser has received funding from Deutsche Forschungsgemeinschaft (DFG) under Germany's Excellence StrategyEXC 2067/1-390729940, via CRC 889 project A02, and via the Leibniz programme. Dominik Oliver has received funding from Deutsche Forschungsgemeinschaft (DFG) via SPP 1608 (OL 240/4-2), GRK 2213 project 2D, and by FOR 5046 (OL 240/8-1).

The funders had no role in study design, data collection and analysis, decision to publish, or preparation of the manuscript.

Copyright: (C) 2020 Moser T et al. This is an open access article distributed under the terms of the Creative Commons Attribution License, which permits unrestricted use, distribution, and reproduction in any medium, provided the original work is properly cited.

How to cite this article: Effertz T, Moser T and Oliver D. Recent advances in cochlear hair cell nanophysiology: subcellular compartmentalization of electrical signaling in compact sensory cells. Faculty Reviews 2020 9:(24) https://doi.org/10.12703/r/9-24

Published: 21 Dec 2020, Faculty Reviews 9:(24) https://doi.org/10.12703/r/9-24 


\section{Introduction}

The organ of Corti inside the cochlea forms the sensory organ of our sense of hearing. It houses two types of mechanosensory hair cells: three rows of outer hair cells (OHCs, approximately 12,000 in the human cochlea) and one row of inner hair cells (IHCs, approximately 3,500) span the entire length of the basilar membrane. Sound-induced vibrations of the tympanic membrane from approximately one $\AA$ are sufficient to elicit hair cell responses while vibrations of hundreds of nm are required to saturate that response. The ensuing receptor potential (RP) drives their key output function: active micromechanics (OHCs) and synaptic sound encoding (IHCs). OHCs and IHCs are highly specialized for operating at the fast pace inherent to auditory signaling. This applies to both the unique motor process of OHCs and the temporal bandwidth of signal transmission at the specialized ribbon synapses in IHCs. A sophisticated set of ion channels enables operation of these processes in the $\mathrm{kHz}$ range (OHCs) and hundreds of $\mathrm{Hz}$ range (IHCs). Both show afferent and efferent innervation but to different extents and serving different functions. Efferent control by medial olivocochlear projections is more prominent at OHCs, where an unconventional cholinergic mechanism inhibits electromotility (eM). Afferent synaptic transmission of IHCs to myelinated type I spiral ganglion neurons (SGNs; type I forming 95\% of all SGNs) mediates cochlear sound encoding, while $\mathrm{OHCs}$ do not seem to contribute to sound encoding but instead signal to unmyelinated type II SGNs, likely to report cochlear damage. Once dysfunctional or lost, OHCs and IHCs cannot be replaced and sensory hearing loss results.

Mammalian hair cells are small and compact cells and therefore are also understood to be electrically compact, i.e. isoelectric. Nevertheless, recently, it has been demonstrated that IHCs of the rodent cochlea can undergo macromolecular and low-resistance electrical coupling to form functional mini-syncytia ${ }^{1}$, indications for which had previously also been reported for hair cells of the avian auditory papilla ${ }^{2}$. OHCs do not seem to engage in such direct coupling ${ }^{1}$ but interact mechanically ${ }^{3}$. More generally, neighboring hair cells face a common mechanical input resulting from the sound-driven traveling wave. At a subcellular level, it has become increasingly clear that essentially all of the various membrane specializations that generate and shape their electrical signals (i.e. RPs) on the one hand and the effectors that drive the cell's output in response to the RP on the other hand are assembled into spatially confined membrane nanodomains rather than evenly distributed across the isoelectric membrane.

The higher-level principle governing the subcellular organization of hair cells is their nature as epithelial cells, imposing structural and functional polarization of the cell surface into apical and basolateral membranes. In all hair cells, the mechanoelectrical transduction (MET) machinery that provides the stimulus-modulated transducer conductance is found at the apical pole. Opposing the depolarizing apical MET conductance, basolateral potassium conductances establish the hair cell's negative resting potential, whereby the balance between apical and basolateral conductances defines its actual value estimated as -40 and $-55 \mathrm{mV}$ in $\mathrm{OHCs}$ and IHCs, respectively ${ }^{4}$. Equally important, basolateral channels, including low-voltage activated $\mathrm{Ca}_{2}{ }^{+}$channels, are essential for shaping the RP in terms of both amplitude dynamics and timing.

Finally, the effectors of the RP are also built into the basolateral membrane region. This is where functional divergence between IHCs and OHCs is fundamental: in the basolateral membrane of the IHCs, ribbon-type active zones (AZs) transmit temporal and amplitude information contained in the RP with unprecedented precision to the postsynaptic auditory neurons. In $\mathrm{OHCs}$, in contrast, the RP primarily drives ultrafast cell length changes, termed eM, by a machinery that occupies large parts of the basolateral membrane domain.

In recent years, the nanoscale organization of several functional modules and their molecular constituents (and their interactions) has been resolved. While in some cases the physiological meaning of compartmentalization is well understood, e.g. to provide nanoscale coupling by the diffusible messenger $\mathrm{Ca}^{2+}$ or to avoid cross-talk of intracellular signals, in other cases the underlying subcellular physiology remains unknown or speculative. Here we attempt to describe recent progress in understanding the subcellular compartmentalization of membrane physiology in cochlear hair cells, the molecular composition of identified domains, and their functional relevance.

\section{The apical membrane: mechanoelectrical transduction}

Molecular composition of the MET channel complex

A supramolecular MET complex is located at the tips of all but the tallest row of stereocilia, thus defining a highly specialized and spatially extremely confined domain (Figure 1) that also includes a specific membrane lipid composition (see below) and an interaction with a distinct lateral membrane domain in the neighboring, larger stereocilium, connected via the tip link.

Recent data show that the auditory MET complex involves intricate interactions among a set of proteins (i.e. transmembrane channel-like protein isoform-1/2 [TMC1/2 $]^{5,6}$, lipoma HMGIC fusion partner-like 5 [LHFPL5] $]^{7,8}$, transmembrane inner ear $[\text { TMIE }]^{9,10}$, calcium- and integrin-binding protein $2[\mathrm{CIB} 2]^{11}$, and protocadherin 15 [PCDH15 ${ }^{12}$ ) and membrane lipids such as phosphatidylinositol-4,5-bisphosphate $\left(\mathrm{PIP}_{2}\right)^{10,13,14}$ (Figure 1). Adding to the molecular intricacy of the MET complex is the variable temporal expression of its components reflected in an ongoing maturation process up until and after the onset of hearing, of which the TMC1/2 proteins are only one example ${ }^{15-17}$.

TMC1/2 proteins constitute a core component of the MET complex and are now thought to contribute to its pore-forming subunits $^{5,6,16,18-26}$. While TMC2 is only transiently expressed in auditory hair cells during early postnatal development, TMC1 expression rises gradually and is essential for adult auditory MET $^{25}$. Evidence for TMC proteins forming the MET pore comes, among others, from chemical modification of introduced 


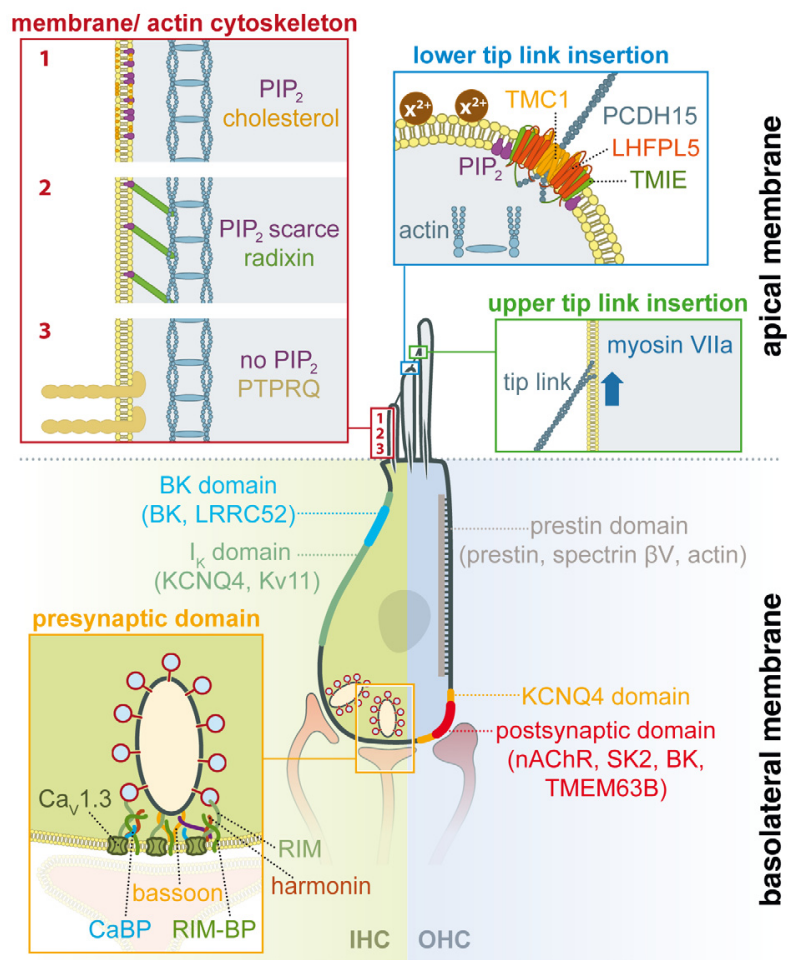

Figure 1. Domain organization of functional modules in the plasma membrane of inner hair cells (IHCs) and outer hair cells (OHCs). Top section: At the apical pole, the function and structural organization of mechanoelectrical transduction (MET) is similar for both hair cell types. Enlarged insets show simplified representations of stereociliary domains as defined by protein and lipid content as well as by function. Two major protein complexes define highly specialized domains that mediate MET and are located at the upper (green box) and lower (blue box) tip link insertion points (note that only a selection of proteins are shown for space reasons). At the lower tip link insertion point, the lower end of the tip link (protocadherin 15 [PCDH15] dimer) makes contact with the MET channel complex, where transmembrane channel-like protein isoform-1 (TMC1) and transmembrane inner ear (TMIE) are thought to constitute the MET channel pore and further components, including lipoma HMGIC fusion partner-like 5 (LHFPL5), phosphatidylinositol-4,5-bisphosphate $\left(\mathrm{PIP}_{2}\right)$, and divalent cations, $\left(\mathrm{X}^{2+}\right)$ affect pore properties and adaptation. At the upper tip link insertion point, myosin VIla is now thought to maintain the tip link under tension rather than mediating fast adaptation, although modulation of myosin VIla activity may affect the dynamic range of MET responses. Beyond these fundamental MET complexes, the stereociliary membrane (red box) is organized in distinct domains along the length of each stereocilium, which differ in protein and lipid content. Some identified components characterized so far are highlighted in the blow-up cartoons of three distinct regions (labeled 1-3) of each stereocilium. Lower part: The basolateral pole harbors distinct sets of functional modules in IHCs and OHCs, which are therefore shown separately. $\mathrm{K}^{+}$ion channel populations are predominantly located towards the neck region in IHCs (left, light blue) but at a basal cap-like membrane area in OHCs (right, light yellow). Specifically, in OHCs, postsynaptic acetylcholine receptors (AChRs) and their downstream effectors, small conductance $\mathrm{Ca}^{2+}$-activated $\mathrm{K}^{+}$channels, are clustered at the subsynaptic membrane of efferent cholinergic synapses. In both cell types, $\mathrm{K}^{+}$channel positioning is reciprocal to the localization of the predominant effector modules. In the case of the $\mathrm{IHC}$, this is the functionally heterogenous population of ribbon-type active zones each holding a $\mathrm{Ca}^{2+}$ channel cluster. The presynaptic scaffold bassoon, anchoring the ribbon and contributing to clustering CaV1.3 $\mathrm{Ca}^{2+}$ channels, is highlighted in the inset (orange box). The Ca ${ }^{2+}$ channel complex is composed primarily of the $\mathrm{CaV} 1.3 \alpha$, the $\mathrm{CaV} \beta 2$, and $\mathrm{CaV} \alpha 2 \delta 2$ subunits and of interacting proteins such as $\mathrm{Ca}^{2+}$-binding proteins (CaBPs), harmonin, Rab3-interacting molecules (RIMs), and RIM-binding proteins (RIM-BPs). In the OHC, the entire lateral membrane is occupied by the machinery that generates electromotility ("prestin domain"), including densely packed prestin in the membrane and a poorly characterized actin-associated submembrane scaffold, lined by subsurface membrane compartments (cisternae). BK, Ca ${ }^{2+}$-activated potassium channel; LRRC, leucine-rich-repeat-containing; $n A c h R$, nicotinic acetylcholine receptor; PTPRQ, protein tyrosine phosphatase receptor type Q; SK2, small conductance $\mathrm{Ca}^{2+}$-activated potassium channel; TMEM63B, transmembrane protein 63B.

cysteine residues, which altered ion selectivity of the MET currents $6,8,27$. Homology modeling of TMC structure with TMEM16 predicts two separate pores in a dimeric TMC complex, located at the margin of each subunit ${ }^{24,25}$. Interestingly, this model would see the pore "open" to the surrounding lipid bilayer laterally, rather than fully surrounded by protein. However, the TMC architecture might be complemented by TMIE, closing the pore towards the lipid bilayer ${ }^{10}$. Direct evidence that $\mathrm{TMC} 1 / 2$ proteins can form mechanosensitive ion channels was recently shown when orthologues of human TMC1/2 were successfully purified and reconstituted in liposomes and their mechanosensitivity demonstrated ${ }^{26}$. This study used CmTMC1 (green sea turtle, Chelonia mydas) and MuTMC2 (budgerigar, Melopsittacus undulatus), which possess $72 \%$ and $66 \%$ sequence identity 
to human TMCs, respectively. Verification of mechanogating for mammalian TMC1 as well as further evidence in support of the current model of TMC1 dimers with two independent pores $^{25}$ will require future work. Of note, while quasi-simultaneous ${ }^{27,28}$ opening of both pores seems possible, their simultaneous closure is harder to envision. A temporally linked but separated closing of two pores, consistent with stochastic single pore properties, has not been observed directly in previous single channel recordings ${ }^{14,29,30}$.

\section{MET current adaptation}

Traditionally and primarily based on work in turtle and bullfrog hair cells, adaptation of the MET current was thought to be an exclusively $\mathrm{Ca}^{2+}$-driven process ${ }^{31-33}$ that modulates the MET channel's resting open probability and thus its dynamic current/ stimulus relationship ${ }^{34-36}$. $\mathrm{Ca}^{2+}$ was thought to interact either with the MET channel itself ${ }^{32,37,38}$ or act on myosin motors ${ }^{33,39,40}$ that slip or climb along the stereocilia actin core, thus controlling tip link tension. However, data showed that MET channels are present only at the tip of stereocilia and the presumed myosin "adaptation" motors at the upper tip link insertion point, making a modulation of those motors by $\mathrm{Ca}^{2+}$ entering through the MET channel unlikely.

After some controversial data on the matter ${ }^{41-43}$, recently, three different mechanisms controlling the MET channel resting open probability were proposed: i) a resting tension-generating, myosin-based process ${ }^{44,45}$ (Figure 1), ii) a fast, $\mathrm{Ca}^{2+}$-independent adaptation process $^{41}$, and iii) an effect of extracellular $\mathrm{Ca}^{2+}$ that interacts with the lipid bilayer and modulates membrane stiffness ${ }^{44}$.

Reconciliation of $\mathrm{Ca}^{2+}$-dependent and $\mathrm{Ca}^{2+}$-independent models for adaptation came from comparison of the different stimulus methods used in previous studies. Where a fluid jet stimulates the hair bundle with a steady force (force clamp), a stiff probe stimulates the hair bundle with a constant displacement (displacement clamp). These two stimulation paradigms can either obscure or reveal $\mathrm{Ca}^{2+}$-dependent and -independent processes $^{46}$. These data also suggested that the "natural" stimuli detected by IHCs and OHCs are different: the free-standing IHCs are driven by force (as with the fluid jet), while the OHCs are stimulated by displacement prescribed by the overlying tectorial membrane, which $\mathrm{OHC}$ hair bundles are connected to (as with the stiff probe) ${ }^{42}$.

\section{Lipid-MET channel complex interactions}

In addition to the involved proteins and $\mathrm{Ca}^{2+}$ ions, the lipid bilayer, its organization, and its nanodomain properties are most certainly important for normal MET channel function. Close functional interaction of ion channel complexes with their lipid environment is a well-established concept ${ }^{47-60}$ (for review, see 61) and has recently become recognized more in auditory MET research ${ }^{10,13,14,62,63}$. For example, modulation of MET channel function by $\mathrm{PIP}_{2}$ was originally described in bullfrog hair cells ${ }^{13}$ and also demonstrated in murine $\mathrm{IHCs}^{14}$. Models on the role of the cell membrane for MET include the formation of cholesterol-rich force foci ${ }^{64}$, the relaying of force ${ }^{44}$, activation and/or modulation of MET channels ${ }^{63}$, or action as a functional cofactor of MET channel complexes ${ }^{10,13,14,62,65}$ (short review see 56).

\section{Distinct membrane domains along the mechanosensory stereocilium}

While we are missing membrane composition data for IHCs and OHCs, some data derived from chick and bullfrog hair cells are available. These data show that even the membrane of each stereocilium shows distinct membrane domains along its height of just a few $\mu m^{66-68}$ (Figure 1). Formation of membrane nanodomains containing distinct subsets of proteins and a close linkage between the actin core of stereocilia and the cell membrane were demonstrated for chick vestibular hair cells ${ }^{66}$. These data showed, for example, that cholesterol was enriched at the tips of stereocilia, where it potentially stiffens the membrane and could function as a force focus for the MET complex ${ }^{61,64,69}$. Other data also showed that $\mathrm{PIP}_{2}$ modulates core MET channel properties ${ }^{13,14}$, possibly due to direct interaction with $\mathrm{TMIE}^{10}$. Moreover, while PIP likely interacts with the MET complex, it is completely absent from the stereocilia ankle region, where PTPRQ, a putative lipid phosphatase, or radixin are prominently localized ${ }^{66,67}$. Likewise, the shaft region of each stereocilium shows a high concentration of the $\mathrm{Ca}^{2+}$ pump PMCA2 ${ }^{66}$, which seems critical for $\mathrm{Ca}^{2+}$ clearance and in forming a distinct separation of cytosolic $\mathrm{Ca}^{2+}$ pools between stereocilia tips and ankles. Taken together, the data found in the non-auditory MET fields are so compelling $48,49,52,56,58,60,61$ that a close inspection of the dependence of the auditory MET complex on its cell membrane environment is warranted.

However, a detailed proteomic or lipidomic analysis of the stereociliary membrane in murine hair bundles is currently missing but necessary, as lipid domain differences between chick vestibular hair bundles and auditory murine hair bundles are known ${ }^{14,66}$. New methods, both nanoscopic and "omic", will be required for investigating the morphology and dynamics of stereocilia nanodomains that are below the optical resolution limit of conventional light microscopes.

\section{The basolateral membrane}

Prestin-based electromotility

In the $\mathrm{OHC}$, the RP drives eM, which is mediated by prestin (SLC26A5, Figure 1), a member of the SLC26 anion transporter family. Biophysical considerations and a wealth of experimental data indicate that voltage-dependent conformational rearrangements of prestin alter its dimension in the membrane, which at the population level translates into surface area changes of the membrane and hence cellular shape changes (area motor mechanism; for a comprehensive review, see 70). The predominant view for many years has been that this process is ultrafast, i.e. following acoustic frequencies far into the ultrasonic range (measurements ranging up to $80 \mathrm{kHz}^{71}$ ). Such speed is the underlying assumption for many models of cochlear amplification, where eM amplifies cochlear vibration 
in a cycle-by-cycle manner. However, a series of recent detailed analyses of prestin and eM kinetics challenged this view, reporting lowpass behavior with corner frequencies at around $20 \mathrm{kHz}$, well below the upper frequency limit of hearing in many mammals, which obviously urges a reconsideration of the mechanism of cochlear amplification ${ }^{72,73}$.

Recent advances at the structural level are beginning to shed light on the molecular mechanisms underlying eM. Combined homology modeling, molecular dynamics simulations, and functional analysis clarified the membrane architecture and domain organization of the prestin protomer, showing a $7+7$ inverted repeat architecture, and organization into two major opposing domains, tentatively termed gate and core domains ${ }^{74}$. This model was soon confirmed by the first experimental crystallographic structure of a bacterial SLC26 homolog ${ }^{75}$. Subsequent structural and biochemical analysis revealed that SLC26 proteins, including prestin, are dimers ${ }^{76}$. Finally, the first experimental structure of a eukaryotic homolog, mouse SLC26A9, recently uncovered additional details, particularly on substrate binding and unexpected involvement of the conserved intracellular C-terminus (STAS domain) in the dimerization of SLC26 proteins ${ }^{77}$. Together, all of these structural findings suggest that SLC26 transporters may act by an elevator mechanism, in which a mobile domain (core or transport domain) binds the substrate and delivers it to the other side of the membrane by a rotational-translational movement, with the other main domain (gate or scaffold domain) acting as a static scaffold. It will be exciting to see if the eM mechanism of prestin can also be understood in the framework of such an elevator mechanism.

Irrespective of the molecular details, the area motor mechanism requires large numbers of elementary motors in series to generate substantial macroscopic cellular motion or force. In fact, the entire lateral membrane consists of a dense array of particles believed to be individual prestin molecules ${ }^{78}$, whereas the basal area of the membrane is largely devoid of prestin (e.g. see 79), establishing a clear-cut segregation of the basolateral membrane into a lateral "prestin domain" and a basal subnuclear cap that essentially contains all other signaling functionality. This segregation goes along with low diffusional mobility of prestin in the lateral domain ${ }^{80}$.

Remarkably, in contrast to progress in understanding the molecular mechanisms of prestin, how the prestin domain is organized and held together has remained enigmatic. The OHC lateral wall is a multi-layered structure that, beyond the prestin-populated plasma membrane (Figure 1), also features a highly regular submembrane actin lattice and one or more subsurface cisternae that line up with most of the lateral membrane ${ }^{78}$. One identified component of this structure is the nonconventional spectrin $\beta \mathrm{V}^{81}$, whose localization to the lateral membrane parallels the evolutionary emergence of the lateral prestin domain $^{82}$. Electron tomography revealed an even higher complexity and regularity of the entire trilaminate structure, including regularly spaced filamentous connectors between the actin lattice and both the plasma membrane and the cisternal membrane ${ }^{83}$. However, the identity of these components and their contribution to the formation and function of the prestin domain remain unknown. There is some evidence that prestin itself contributes to establishing lateral membrane identity in $\mathrm{OHCs}$, as its genetic deletion leads to the relocation of other membrane proteins from their usual place into the lateral membrane ${ }^{84}$. A specific lipid composition may also contribute to the identity of the prestin domain. Thus, prestin's diffusional mobility and function depend on cholesterol content ${ }^{80,85}$, and spectrin $\beta \mathrm{V}$ connects to the membrane via a phosphoinositidespecific $\mathrm{PH}$ domain ${ }^{82}$.

\section{Domain organization of basolateral ion channels}

OHCs. OHCs are characterized by a large basolateral $\mathrm{K}^{+}$ conductance that is key to ensuring a fast electrical membrane time constant permissive for alternating current RPs at acoustic frequencies ${ }^{4}$. Such fast electrical oscillation may be required to drive eM cycle-by-cycle (see above). The major OHC current is known as $I_{K, n}$ for its unusually negative voltage range of activation, resulting in constitutive activity at physiological membrane voltages. The underlying $\mathrm{K}^{+}$channels contain the pore-forming KCNQ4 subunit $(\mathrm{Kv} 7.4)^{86}$. KCNQ4 proteins localize to the basal cap of the $\mathrm{OHC}^{86}$. This localization appears straightforward in avoiding interference with the high prestin density required in the lateral domain. Moreover, a recent report suggests that clustering of KCNQ4 may enforce cooperativity that alters functional properties ${ }^{87}$. In particular, clustering was shown to speed up gating kinetics and contribute to shifting the voltage range of activation, which in $\mathrm{OHCs}$ is much more negative than of heterologous KCNQ4 channels, a puzzle so far unexplained.

At least three additional ion channels are also clustered in the basal KCNQ4-positive domain (Figure 1): $\alpha 9 / 10$ nicotinic ACh receptors as well as $\mathrm{SK} 2$ and $\mathrm{BK} \mathrm{Ca}^{2+}$-activated $\mathrm{K}^{+}$channels. These three channel types constitute the postsynaptic ion channel complement of cholinergic olivocochlear inhibitory synapses and mediate unusual inhibitory postsynaptic potentials by an indirect ionotropic mechanism: the hair cell's ionotropic $\alpha 9 / \alpha 10$ cholinergic receptors are highly $\mathrm{Ca}^{2+}$-permeable channels ${ }^{88} \cdot \mathrm{Ca}^{2+}$ influx rapidly activates colocalized $\mathrm{Ca}^{2+}$-activated $\mathrm{K}^{+}$channels, resulting in net outward current and hence hyperpolarization. For a long time, it has been known that small-conductance SK2 channels mediate the outward current, and accordingly their localization is confined to the subsynaptic membrane, outlining this functional domain ${ }^{89,90}$ (Figure 1). However, large-conductance BK channels also contribute to the cholinergic hyperpolarization, particularly in the mid- to high-frequency regions of the cochlea. Indeed, BK and SK2 channels co-occupy the same synaptic membrane area ${ }^{91,92}$.

A recent unexpected addition to the ion channel complement at this domain is TMEM63B ${ }^{93}$. TMEM63B forms $\mathrm{Ca}^{2+}$-permeable cation channels activated by hypo-osmotic stress. It was shown that upon osmotic swelling of OHCs, TMEM63B channels are activated and initiate a regulatory volume decrease, presumably 
by activating cation efflux via $\mathrm{Ca}^{2+}$-activated $\mathrm{K}^{+}$channels. Indeed, TMEM63B proteins are colocalized with SK2 channels in OHCs, suggesting that they, too, are part of the efferent postsynaptic membrane. The osmosensory function of TMEM63B appears to be important for $\mathrm{OHC}$ maintenance, since genetic deletion results in $\mathrm{OHC}$ degeneration and hearing loss ${ }^{93}$.

As for the prestin domain, the mechanisms and molecular interactions that target and restrict ion channels to their basal territory remain to be elucidated. Nevertheless, the spatial separation of basal channel domain and lateral prestin domain first emerges during postnatal development in rodents and is dependent on thyroid hormone signaling ${ }^{79,90}$, which might provide an experimental entry point towards the identification of molecular components and mechanisms involved in domain formation ${ }^{94}$.

IHCs. IHCs express a surprisingly complex repertoire of basolateral potassium channels that has only recently been dissected in detail ${ }^{95}$. For decades, three major $\mathrm{K}^{+}$conductances have been known, set apart by their distinct activation kinetics, voltage dependence, and pharmacology. The molecular identity of the channels that mediate two of these components (historically termed $\mathrm{I}_{\mathrm{K}, \mathrm{f}}$ for the fast activation kinetics and $I_{K, n}$ for the particularly negative activation voltage range) is well understood. Large-conductance $\mathrm{BK}$ channels underlie $\mathrm{I}_{\mathrm{K}, \mathrm{f}}^{96,97}$, and KCNQ4 (Kv7.4) channels mediate $\mathrm{I}_{\mathrm{K}, \mathrm{n}}{ }^{98}$. However, the channel(s) underlying the slowly activating $\mathrm{K}^{+}$ current $\mathrm{I}_{\mathrm{K}, \mathrm{s}}$ remained unknown. Dierich et al. ${ }^{95}$ combined expression data with pharmacology and biophysical characterization to dissect $\mathrm{I}_{\mathrm{K}, \mathrm{s}}$ and found that it is mediated by $\mathrm{K}_{\mathrm{v}} 1.8$, $\mathrm{K}_{v} 11.1$, and $\mathrm{K}_{v} 12.1$ channels. Modeling IHC RPs indicated that the complex $\mathrm{K}^{+}$channel complement helps to ensure temporally precise signal encoding over a wide dynamic range ${ }^{95}$.

Under the assumption that the IHC is electrically compact, there is no obvious reason for spatial segregation of these channels, and an electrical point model was sufficient to produce all the properties of recorded RPs. Nevertheless, BK distribution is highly clustered into patches close to the neck region of $\mathrm{IHCs}^{97}$ (Figure 1). This is particularly surprising since BK channels generally require elevated $\mathrm{Ca}^{2+}$ for activation within physiological voltage ranges ${ }^{99}$, whereas IHC $\mathrm{Ca}^{2+}$ channels are compartmentalized into the presynaptic zone of the IHC (see below), too far away to supply BK clusters with $\mathrm{Ca}^{2+}$ signals. Two papers now reveal a molecular mechanism that elegantly reconciles both issues: IHCs express LRRC52 as a BK-interacting protein ${ }^{100,101}$. LRRC52 acts as a gating modifier, strongly shifting the voltage sensitivity into a range that matches the hair cell's physiological membrane potential even in the absence of elevated $\mathrm{Ca}^{2+101}$, a property previously determined for $\mathrm{BK}$ channels in $\mathrm{IHCs}^{102}$. Moreover, LRRC52 is responsible for clustering BK at the cell's neck region, where basolateral $\mathrm{Ca}^{2+}$ signaling is out of reach ${ }^{101}$.

What about localization of the other $\mathrm{K}^{+}$channel populations in the same cell? Lower-resolution immunohistochemistry is consistent with predominant localization of $\mathrm{KCNQ} 4$ to the upper part of the lateral membrane ${ }^{98}$. Similarly, Kv11.1 immunoreactivity is mainly found in the upper half of the lateral membrane ${ }^{95}$.

The physiological meaning of molecular sequestration of $\mathrm{BK}$ into distinct clusters and together with the other $\mathrm{K}^{+}$channel entities into the upper region of the IHC remains elusive; a possible rationale may be to keep large $\mathrm{K}^{+}$outward fluxes away from the synapses, where they could depolarize the postsynaptic endings, interfering with precise signal encoding ${ }^{103}$.

\section{Transmitter release by IHCs}

During the last few years, substantial progress has been made toward the understanding of hair cell synaptic transmitter release, and much has been covered in elaborate reviews ${ }^{104-109}$. Hallmarks of the hair cell synapses are i) electron-dense synaptic ribbons, which provide AZ scaffolding, supply synaptic vesicles (SVs) and require the core component $\mathrm{RIBEYE}^{110,111}$ and the anchoring scaffold bassoon ${ }^{112-115}$, ii) exocytosis at high rates and with utmost temporal precision that is sustained over long periods of time by efficient endocytic SV recycling and SV replenishment to the large readily releasable pool of $\mathrm{SVs}^{110,116-124}$, and iii) heterogeneity of presynaptic structure and function that likely enables IHCs to decompose sound intensity information into different neural channels ${ }^{125-129}$.

Release occurs at presynaptic AZs, which are highly specialized nanodomains of the basolateral IHC membrane (Figure 1). It has become clear that the underpinning molecular composition deviates from that of conventional synapses and even from retinal ribbon synapses, likely to support the specific functional requirements of synaptic sound encoding (recent review in 104,108). For example, the $\mathrm{Ca}_{\mathrm{v}} 1.3$-based ${ }^{130-132}$ presynaptic $\mathrm{Ca}^{2+}$ channel complex is active already at the IHC resting potential at the subset of synapses that likely encode soft sounds and inactivates fairly little to reliable signal sound intensity. Beyond splicing of the pore-forming $\mathrm{Ca}_{\mathrm{v}} 1.3 \alpha$ subunit ${ }^{126,133}$, choice of the auxiliary $\mathrm{Ca}_{\mathrm{v}} \beta$ and $\mathrm{Ca}_{\mathrm{v}} \alpha 2 \delta$ subunits ${ }^{134-136}$, interacting proteins such as $\mathrm{Ca}^{2+}$-binding proteins ${ }^{137,138}$, harmonin ${ }^{126,139}$, $\mathrm{RIMs}^{121,140}$, and RIM-BPs ${ }^{120}$ shape the precise biophysical properties of the channels at a given AZ (Figure 1).

$\mathrm{Ca}_{\mathrm{v}} 1.3$ channel complexes are clustered at a very high density of approximately 3,000 channels per $\mu^{2}$ at the large ribbon-type AZs (approximately $\left.0.04 \mu \mathrm{m}^{2}\right)^{127}$ of transmitter release of the basolateral IHC membrane, while estimates of the extrasynaptic channel density are much lower $\left(<10\right.$ channels per $\mu \mathrm{m}^{2}$ in mature IHCs $)^{141}$. This compartmentalization of $\mathrm{Ca}^{2+}$ influx requires the action of multidomain proteins of the AZ: their deletion generally reduces the number of $\mathrm{Ca}^{2+}$ channels available for triggering $\mathrm{SV}$ release $\mathrm{e}^{114,120,121}$ and can also alter the $\mathrm{Ca}^{2+}$ channel topography ${ }^{120,127}$. In the case of bassoon deletion, $\mathrm{Ca}^{2+}$ channels do not properly cluster ${ }^{127}$. Interestingly, even deletion of RIBEYE, not suspected to directly interact with $\mathrm{Ca}^{2+}$ channels, altered the topography and function of the $\mathrm{Ca}^{2+}$ channels ${ }^{110}$. The multidomain proteins of the AZ and the "superscaffolding" 
synaptic ribbon are likely to stabilize the $\mathrm{Ca}^{2+}$ channel cluster that faces massive membrane turnover due to exocytosis and endocytosis at the $\mathrm{AZ}$ and periactive zone membrane domains, respectively. So far, estimates of $\mathrm{Ca}^{2+}$ channel mobility have not been obtained for hair cell AZs, but studies in cultured neurons imply that it might be substantial ${ }^{142}$.

Single channel properties of $\mathrm{Ca}_{\mathrm{v}} 1.3$-based $\mathrm{Ca}^{2+}$ channels of hair cells have been assessed by cell-attached recordings ${ }^{143-149}$ as well as by non-stationary variance analysis ${ }^{127,150,151}$. There is consensus on the average total number of activatable $\mathrm{Ca}^{2+}$ channels per AZ (100) but likely method-related partial discrepancies for estimates of open probability and single channel current. Interestingly, evidence for cooperative gating, revealed for heterologously expressed $\mathrm{Ca}_{\mathrm{v}} 1.3$ channels ${ }^{152}$, has not been reported thus far. Recently, the presynaptic complement $\mathrm{Ca}^{2+}$ channel was revisited using $\mathrm{Ca}^{2+}$ imaging ${ }^{126,127,153,154}$, and a range of 20-300 channels per AZ was estimated ${ }^{127}$. Such massive differences in $\mathrm{Ca}^{2+}$ channel clustering are likely to impact their biophysical properties and the coupling of $\mathrm{Ca}^{2+}$ influx to $\mathrm{SV}$ release. Indeed, recently, it was shown that AZs vary in the control of exocytosis by $\mathrm{Ca}^{2+}$ influx ${ }^{155}$. However, the expectation that membrane nanodomains with a high density of $\mathrm{Ca}^{2+}$ channels might present an active local depolarization exceeding the overall hair cell potential seems not to be supported: the voltage dependence of activation does not correlate positively with the maximal $\mathrm{Ca}^{2+}$ influx ${ }^{126}$. A negative feedback to presynaptic $\mathrm{Ca}^{2+}$ influx is mediated by the release of protons during SV exocytosis that partially inhibit the $\mathrm{Ca}^{2+}$ channels under physiological $\mathrm{pH}$ buffering ${ }^{156}$, and a potential modulation of the IHC $\mathrm{Ca}^{2+}$ channel by lipids ${ }^{157,158}$ remains to be elucidated. Despite the heterogeneity of the control of exocytosis by $\mathrm{Ca}^{2+}$ influx among hair cell AZs, the voltage dependence of $\mathrm{Ca}^{2+}$ influx generally predicts that of $\mathrm{SV}$ release ${ }^{155}$. Site-specific trafficking of components of the $\mathrm{Ca}^{2+}$ channel complex might involve adapter proteins such as Gipc $3^{126}$, and differences in the capacity of tethering multidomain proteins available at the $\mathrm{AZ}^{114,120,121}$ likely contribute to the heterogeneous $\mathrm{Ca}^{2+}$ channel complement. Recently, several candidate mechanisms for setting up AZ heterogeneity have been proposed: planar cell polarity signaling ${ }^{159}$, instruction by postsynaptic neurons ${ }^{160}$, and efferent olivocochlear signaling ${ }^{161}$. Finally, from the perspective of sound coding in the auditory system, it will be of utmost importance to elucidate how properties of the presynaptic AZs relate to the functional ${ }^{162-166}$ and molecular ${ }^{128,129,160,167}$ diversity of SGNs.

\section{Conclusion}

In summary, the auditory hair cells provide an impressive model system for compartmentalization of electrical signaling in compact cells. Already the mechanosensory hair bundle shows different compartments and sub-domains which are essential for the reception and processing of mechanical stimuli. This is likely true for the largest $(5 \mu \mathrm{m})$ and smallest $(<500 \mathrm{~nm})$ stereocilia. Although our technological means are insufficient, as of yet, to directly investigate the interplay of single lipid molecules or rafts with different proteins, pharmacological and genetic manipulations show a close interaction between the cell membrane and proteins, where alterations in either can cause deafness. Understanding these interactions not only at the tip region (MET-complex) but also along the shaft and in the ankles of stereocilia will be a crucial and painstaking endeavor.

For some functional units, particularly afferent and efferent synapses, co-localization of $\mathrm{Ca}^{2+}$ sources and $\mathrm{Ca}^{2+}$-driven effectors provide the obvious rationale for tight clustering of their components into precisely defined domains. Furthermore, this example also shows how the cellular domain architecture translates into functional separation of events even in a compact cell. Thus, in prehearing IHCs, transient efferent innervation results in interspersed afferent and efferent synapses, both driven by $\mathrm{Ca}^{2+}$ signals. Although the distances between both structures are in the low $\mu \mathrm{m}$ range, $\mathrm{Ca}^{2+}$ signals produced at efferent sites fail to elicit vesicular release at nearby afferent presynapses, demonstrating that the functional architecture associated with each domain and the efficient cellular $\mathrm{Ca}^{2+}$ handling ensure functional isolation ${ }^{168}$.

Moreover, detailed studies of the molecular components of the IHC ribbon synapse showcase how subcellular membrane domains are assembled. Nevertheless, it will be an important task for the future to elucidate how differential control of SV release by $\mathrm{Ca}^{2+}$ channels is established, potentially by varying the topography of release sites and $\mathrm{Ca}^{2+}$ channels or simply by domain overlap in the case of large $\mathrm{Ca}^{2+}$ channel clusters. The fascinating question of how hair cells establish subcellular heterogeneity among their $\mathrm{Ca}^{2+}$ channel clusters and, more generally, the membrane nanodomains of the AZs remains to be elucidated.

A similarly stringent analysis of the makeup of the other basolateral domains, in particular the OHC lateral membrane, is still outstanding and promises to reveal important insights into the micro- and nano-mechanics of electromotility.

Finally, in addition to the sophisticated assemblies of membrane proteins and membrane-associated proteins, local differences in lipid composition across the various domains are likely to contribute to their identity and functionality. Tools for tracking and manipulating individual lipid species in living cells have been developed in recent years ${ }^{169,170}$ and promise to provide insights into the role of lipids in hair cell function.

\section{Acknowledgements}

The authors would like to thank Michael Leitner (Institute of Physiology, Department of Physiology and Medical Physics, Medical University of Innsbruck, Austria) for helpful discussions and Jakob Neef (Institute for Auditory Neuroscience \& InnerEarLab University Medical Center Goettingen, Goettingen, Germany) for critically reading the manuscript. 
1. Jean $\mathrm{P}$, Anttonen T, Michanski S, et al.: Macromolecular and electrical coupling between inner hair cells in the rodent cochlea. Nat Commun. 2020; 11(1): 3208 PubMed Abstract | Publisher Full Text | Free Full Text

2. Fischer FP, Brix J, Singer I, et al.: Contacts between hair cells in the avian cochlea. Hear Res. 1991; 53(2): 281-92. PubMed Abstract | Publisher Full Text

3. Zhao HB, Santos-Sacchi J: Auditory collusion and a coupled couple of outer hair cells. Nature. 1999; 399(6734): 359-62. PubMed Abstract | Publisher Full Text

4. Johnson SL, Beurg M, Marcotti W, et al.: Prestin-driven cochlear amplification is not limited by the outer hair cell membrane time constant. Neuron. 2011; 70(6): 1143-54

PubMed Abstract | Publisher Full Text | Free Full Text | Faculty Opinions Recommendation

5. P Pan B, Géléoc GS, Asai Y, et al:: TMC1 and TMC2 are components of the mechanotransduction channel in hair cells of the mammalian inner ear. Neuron. 2013; 79(3): 504-15

PubMed Abstract | Publisher Full Text | Free Full Text | Faculty Opinions Recommendation

6. Pan B, Akyuz N, Liu XP, et al.: TMC1 Forms the Pore of Mechanosensory Transduction Channels in Vertebrate Inner Ear Hair Cells. Neuron. 2018; 99(4): 736-753.e6.

PubMed Abstract | Publisher Full Text | Free Full Text | Faculty Opinions Recommendation

7. Xiong W, Grillet N, Elledge HM, et al:: TMHS is an integral component of the mechanotransduction machinery of cochlear hair cells. Cell. 2012; 151(6): 1283-95.

PubMed Abstract | Publisher Full Text | Free Full Text Faculty Opinions Recommendation

8. Beurg M, Xiong W, Zhao B, et al:: Subunit determination of the conductance of hair-cell mechanotransducer channels. Proc Natl Acad Sci U S A. 2015; 112(5): 1589-94.

PubMed Abstract | Publisher Full Text | Free Full Text

9. Zhao B, Wu Z, Grillet N, et al:: TMIE is an essential component of the mechanotransduction machinery of cochlear hair cells. Neuron. $2014 ; 84(5)$ : 954-67.

PubMed Abstract | Publisher Full Text | Free Full Text

10. Cunningham CL, Qiu X, Wu Z, et al.: TMIE Defines Pore and Gating Properties of the Mechanotransduction Channel of Mammalian Cochlear Hair Cells. Neuron. 2020; 107(1): 126-143.e8. PubMed Abstract | Publisher Full Text | Free Full Text Faculty Opinions Recommendation

11. Giese APJ, Tang YQ, Sinha GP, et al:: CIB2 interacts with TMC1 and TMC2 and is essential for mechanotransduction in auditory hair cells. Nat Commun. 2017; 8(1): 43.

PubMed Abstract | Publisher Full Text | Free Full Text

12. $\mathrm{Ge} \mathrm{J}$, Elferich J, Goehring A, et al.: Structure of mouse protocadherin 15 of the stereocilia tip link in complex with LHFPL5. eLife. 2018; 7: e38770. PubMed Abstract | Publisher Full Text | Free Full Text | Faculty Opinions Recommendation

13. Hirono M, Denis CS, Richardson GP, et al:: Hair cells require phosphatidylinositol 4,5-bisphosphate for mechanical transduction and adaptation. Neuron. 2004; 44(2): 309-20.

PubMed Abstract | Publisher Full Text | Faculty Opinions Recommendation

14. Effertz T, Becker L, Peng AW, et al.: Phosphoinositol-4,5-Bisphosphate Regulates Auditory Hair-Cell Mechanotransduction-Channel Pore Properties and Fast Adaptation. J Neurosci. 2017; 37(48): 11632-46. PubMed Abstract | Publisher Full Text | Free Full Text

15. W Wu Z, Grillet N, Zhao B, et al:: Mechanosensory hair cells express two molecularly distinct mechanotransduction channels. Nat Neurosci. 2017; 20(1): 24-33.

PubMed Abstract | Publisher Full Text | Free Full Text |

Faculty Opinions Recommendation

16. Corns LF, Jeng JY, Richardson GP, et al:: TMC2 Modifies Permeation Properties of the Mechanoelectrical Transducer Channel in Early Postnatal Mouse Cochlear Outer Hair Cells. Front Mol Neurosci. 2017; 10: 326. PubMed Abstract | Publisher Full Text | Free Full Text

17. Liu S, Wang S, Zou L, et al.: TMC1 is an essential component of a leak channel that modulates tonotopy and excitability of auditory hair cells in mice. eLife. 2019; 8: e47441.

PubMed Abstract | Publisher Full Text | Free Full Text |

Faculty Opinions Recommendation

18. Kurima K, Peters LM, Yang $Y$, et al:: Dominant and recessive deafness caused by mutations of a novel gene, TMC1, required for cochlear hair-cell function. Nat Genet. 2002; 30(3): 277-84. PubMed Abstract | Publisher Full Text
19. Kawashima Y, Géléoc GSG, Kurima K, et al:: Mechanotransduction in mouse inner ear hair cells requires transmembrane channel-like genes. J Clin Invest. 2011; 121(12): 4796-809.

PubMed Abstract | Publisher Full Text | Free Full Text |

Faculty Opinions Recommendation

20. Lin X: Perception of sound and gravity by TMC1 and TMC2. J Clin Invest. 2011; 121(12): 4633-6.

PubMed Abstract | Publisher Full Text | Free Full Text

21. Nakanishi H, Kurima K, Kawashima Y, et al:: Mutations of TMC1 cause deafness by disrupting mechanoelectrical transduction. Auris Nasus Larynx. 2014; 41(5): 399-408.

PubMed Abstract | Publisher Full Text | Free Full Text

22. Kurima K, Ebrahim S, Pan B, et al.: TMC1 and TMC2 Localize at the Site of Mechanotransduction in Mammalian Inner Ear Hair Cell Stereocilia. Cell Rep. 2015; 12(10): 1606-17.

PubMed Abstract | Publisher Full Text | Free Full Text

23. Corns LF, Johnson SL, Kros CJ, et al:: Tmc1 Point Mutation Affects Ca2+ Sensitivity and Block by Dihydrostreptomycin of the Mechanoelectrical Transducer Current of Mouse Outer Hair Cells. J Neurosci. 2016; 36(2): 336-49. PubMed Abstract | Publisher Full Text | Free Full Text

24. Ballesteros A, Fenollar-Ferrer C, Swartz KJ: Structural relationship between the putative hair cell mechanotransduction channel TMC1 and TMEM16 proteins. eLife. 2018; 7: e38433.

PubMed Abstract | Publisher Full Text | Free Full Text | Faculty Opinions Recommendation

25. Corey DP, Akyuz N, Holt JR: Function and Dysfunction of TMC Channels in Inner Ear Hair Cells. Cold Spring Harb Perspect Med. 2019; 9(10) a033506. PubMed Abstract | Publisher Full Text | Free Full Text | Faculty Opinions Recommendation

26. Jia Y, Zhao Y, Kusakizako T, et al.: TMC1 and TMC2 Proteins Are PoreForming Subunits of Mechanosensitive Ion Channels. Neuron. 2020; 105(2): 310-321.e3.

PubMed Abstract | Publisher Full Text | Faculty Opinions Recommendation

27. Beurg M, Cui R, Goldring AC, et al:: Variable number of TMC1-dependent mechanotransducer channels underlie tonotopic conductance gradients in the cochlea. Nat Commun. 2018; 9(1): 2185.

PubMed Abstract | Publisher Full Text | Free Full Text |

Faculty Opinions Recommendation

28. Ursell $\mathrm{T}$, Huang $\mathrm{KC}$, Peterson $\mathrm{E}$, et al.: Cooperative gating and spatial organization of membrane proteins through elastic interactions. PLoS Comput Biol. 2007; 3(5): e81.

PubMed Abstract | Publisher Full Text | Free Full Text

29. Beurg M, Fettiplace $\mathrm{R}, \mathrm{Nam} \mathrm{JH}$, et al:: Localization of inner hair cell mechanotransducer channels using high-speed calcium imaging. $\mathrm{Nat}$ Neurosci. 2009; 12(5): 553-8.

PubMed Abstract | Publisher Full Text | Free Full Text |

Faculty Opinions Recommendation

30. Ricci AJ, Crawford AC, Fettiplace R: Tonotopic Variation in the Conductance of the Hair Cell Mechanotransducer Channel. Neuron. 2003; 40(5): 983-90. PubMed Abstract | Publisher Full Text

31. Ricci AJ, Fettiplace R: The effects of calcium buffering and cyclic AMP on mechano-electrical transduction in turtle auditory hair cells. $J$ Physiol. 1997; 501(Pt 1): 111-24.

PubMed Abstract | Publisher Full Text | Free Full Text

32. Crawford AC, Evans MG, Fettiplace R: Activation and adaptation of transducer currents in turtle hair cells. J Physiol. 1989; 419: 405-34. PubMed Abstract | Publisher Full Text | Free Full Text

33. Howard J, Hudspeth AJ: Mechanical relaxation of the hair bundle mediates adaptation in mechanoelectrical transduction by the bullfrog's saccular hair cell. Proc Natl Acad Sci U S A. 1987; 84(9): 3064-8. PubMed Abstract | Publisher Full Text | Free Full Text

34. Eatock RA, Corey DP, Hudspeth AJ: Adaptation of mechanoelectrical transduction in hair cells of the bullfrog's sacculus. J Neurosci. 1987; 7(9): 2821-36.

PubMed Abstract | Publisher Full Text | Free Full Text

35. Farris HE, Wells GB, Ricci AJ: Steady-state adaptation of mechanotransduction modulates the resting potential of auditory hair cells, providing an assay for endolymph [Ca ${ }^{2+}$. J Neurosci. 2006; 26(48): 12526-36. PubMed Abstract | Publisher Full Text | Free Full Text

36. Gillespie PG, Müller U: Mechanotransduction by hair cells: Models, molecules, and mechanisms. Cell. 2009; 139(1): 33-44.

PubMed Abstract | Publisher Full Text | Free Full Text

37. Cheung ELM, Corey DP: $\mathrm{Ca}^{2+}$ changes the force sensitivity of the hair-cell transduction channel. Biophys J. 2006; 90(1): 124-39. PubMed Abstract | Publisher Full Text | Free Full Text

38. Choe Y, Magnasco MO, Hudspeth AJ: A model for amplification of hair-bundle 
motion by cyclical binding of $\mathrm{Ca}^{2+}$ to mechanoelectrical-transduction channels. Proc Natl Acad Sci U S A. 1998; 95(26): 15321-6. PubMed Abstract | Publisher Full Text | Free Full Text

39. Holt JR, Gillespie SKH, Provance DW, et al.: A Chemical-Genetic Strategy Implicates Myosin-1c in Adaptation by Hair Cells. Cell. 2002; 108(3): 371-81. PubMed Abstract | Publisher Full Text

40. Assad JA, Corey DP: An active motor model for adaptation by vertebrate hair cells. J Neurosci. 1992; 12(9): 3291-309. PubMed Abstract | Publisher Full Text | Free Full Text

41. Peng AW, Effertz T, Ricci AJ: Adaptation of mammalian auditory hair cell mechanotransduction is independent of calcium entry. Neuron. 2013; 80(4): 960-72.

PubMed Abstract | Publisher Full Text | Free Full Text |

Faculty Opinions Recommendation

42. Corns LF, Johnson SL, Kros CJ, et al:: Calcium entry into stereocilia drives adaptation of the mechanoelectrical transducer current of mammalian cochlear hair cells. Proc Natl Acad Sci U S A. 2014; 111(41): 14918-23. PubMed Abstract | Publisher Full Text | Free Full Text

43. Marcotti W, Corns LF, Goodyear RJ, et al.: The acquisition of mechano-electrical transducer current adaptation in auditory hair cells requires myosin VI. J Physiol. 2016; 594(13): 3667-81.

PubMed Abstract | Publisher Full Text | Free Full Text

44. Peng AW, Gnanasambandam R, Sachs F, et al:: Adaptation Independent Modulation of Auditory Hair Cell Mechanotransduction Channel Open Probability Implicates a Role for the Lipid Bilayer. J Neurosci. 2016; 36(10): 2945-56.

PubMed Abstract | Publisher Full Text | Free Full Text

45. Li S, Mecca A, Kim J, et al:: Myosin-VIla is expressed in multiple isoforms and essential for tensioning the hair cell mechanotransduction complex. Nat Commun. 2020; 11(1): 2066.

PubMed Abstract | Publisher Full Text | Free Full Text |

Faculty Opinions Recommendation

46. Caprara GA, Mecca AA, Wang Y, et al.: Hair Bundle Stimulation Mode Modifies Manifestations of Mechanotransduction Adaptation. J Neurosci. 2019; 39(46): 9098-106.

PubMed Abstract | Publisher Full Text | Free Full Text

Faculty Opinions Recommendation

47. Webb RJ, East JM, Sharma RP, et al.: Hydrophobic mismatch and the incorporation of peptides into lipid bilayers: A possible mechanism for retention in the Golgi. Biochemistry. 1998; 37(2): 673-9. PubMed Abstract | Publisher Full Text

48. Patel AJ, Lazdunski M, Honoré E: Lipid and mechano-gated $2 \mathbf{P}$ domain $\mathbf{K}^{+}$ channels. Curr Opin Cell Biol. 2001; 13(4): 422-8. PubMed Abstract | Publisher Full Text

49. Sprong $\mathrm{H}$, van der Sluijs $\mathrm{P}$, van Meer $\mathrm{G}$ : How proteins move lipids and lipids move proteins. Nat Rev Mol Cell Biol. 2001; 2(7): 504-13.

PubMed Abstract | Publisher Full Text

50. Nuchyna TM, Tape SE, Koeppe RE, et al:: Bilayer-dependent inhibition of mechanosensitive channels by neuroactive peptide enantiomers. Nature. 2004; 430(6996): 235-40.

PubMed Abstract | Publisher Full Text | Faculty Opinions Recommendation

51. Li Y, Gamper N, Hilgemann DW, et al.: Regulation of Kv7 (KCNQ) $\mathrm{K}^{+}$channel open probability by phosphatidylinositol 4,5-bisphosphate. J Neurosci. 2005; 25(43): 9825-35.

PubMed Abstract | Publisher Full Text | Free Full Text

52. Kasimova MA, Tarek M, Shaytan AK, et al:: Voltage-gated ion channel modulation by lipids: Insights from molecular dynamics simulations. Biochim Biophys Acta. 2014; 1838(5): 1322-31. PubMed Abstract | Publisher Full Tex

53. Zaydman MA, Cui J: PIP ${ }_{2}$ regulation of KCNQ channels: Biophysical and molecular mechanisms for lipid modulation of voltage-dependent gating. Front Physiol. 2014; 5: 195

PubMed Abstract | Publisher Full Text | Free Full Text

54. Iscla I, Blount P: Sensing and responding to membrane tension: The bacterial MscL channel as a model system. Biophys J. 2012; 103(2): 169-74. PubMed Abstract | Publisher Full Text | Free Full Text

55. Hansen SB, Tao X, Mackinnon R: Structural basis of $\mathrm{PIP}_{2}$ activation of the classical inward rectifier K+ channel Kir2.2. Nature. 2011; 477(7365): 495-8. PubMed Abstract | Publisher Full Text | Free Full Text | Faculty Opinions Recommendation

56. Dart C: Lipid microdomains and the regulation of ion channel function J Physiol. 2010; 588(Pt 17): 3169-78.

PubMed Abstract | Publisher Full Text | Free Full Text |

Faculty Opinions Recommendation

57. Hurst AC, Gottlieb PA, Martinac B: Concentration dependent effect of GsMTx on mechanosensitive channels of small conductance in $E$. coli spheroplasts. Eur Biophys J. 2009; 38(4): 415-25. PubMed Abstract | Publisher Full Text

58. Phillips $\mathrm{R}$, Ursell $\mathrm{T}$, Wiggins $\mathrm{P}$, et al.: Emerging roles for lipids in shaping membrane-protein function. Nature 2009; 459(7245): 379-85. PubMed Abstract | Publisher Full Text | Free Full Text

59. Reeves D, Ursell T, Sens P, et al:: Membrane mechanics as a probe of ion-channel gating mechanisms. Phys Rev E Stat Nonlin Soft Matter Phys. 2008; 78(4 Pt 1): 041901.

PubMed Abstract | Publisher Full Text | Free Full Text

60. Ursell T, Rob P, Jane K, et al.: The Role of Lipid Bilayer Mechanics in Mechanosensation. Caltec. 2007

Publisher Full Text

61. Anishkin A, Loukin $\mathrm{SH}$, Teng J, et al.: Feeling the hidden mechanical forces in lipid bilayer is an original sense. Proc Natl Acad Sci U S A. 2014; 111(22): in lipid bilaye 905 .

7898-905.
PubMed Abstract | Publisher Full Text | Free Full Text

62. Effertz T, Scharr AL, Ricci AJ: Cell membrane organization is important for inne hair cell MET-channel gating. AIP Conf Proc. 2018; 1965: 120006. Publisher Full Text

63. Gianoli F, Risler T, Kozlov AS: Lipid bilayer mediates ion-channel cooperativity in a model of hair-cell mechanotransduction. Proc Natl Acad Sci U S A. 2017; 114(51): E11010-E11019. PubMed Abstract | Publisher Full Text | Free Full Text

64. Anishkin A, Kung C: Stiffened lipid platforms at molecular force foci. Proc Natl Acad Sci U S A. 2013; 110(13): 4886-92.

PubMed Abstract | Publisher Full Text | Free Full Text

65. Tobin M, Chaiyasitdhi A, Michel V, et al.: Stiffness and tension gradients of the hair cell's tip-link complex in the mammalian cochlea. eLife. 2019; 8 : e43473.

PubMed Abstract | Publisher Full Text | Free Full Text | Faculty Opinions Recommendation

66. Zhao $\mathrm{H}$, Williams $\mathrm{DE}$, Shin JB, et al.: Large membrane domains in hair bundles specify spatially constricted radixin activation. J Neurosci. 2012; 32(13): 4600-9. PubMed Abstract | Publisher Full Text | Free Full Text

67. Shin JB, Krey JF, Hassan A, et al:: Molecular architecture of the chick vestibular hair bundle. Nat Neurosci. 2013; 16(3): 365-74.

PubMed Abstract | Publisher Full Text | Free Full Text

68. Metlagel Z, Krey JF, Song J, et al.: Electron cryo-tomography of vestibular hair-cell stereocilia. J Struct Biol. 2019; 206(2): 149-55 PubMed Abstract | Publisher Full Text | Free Full Text | Faculty Opinions Recommendation

69. CGianoli F, Risler T, Kozlov AS, et al.: The Development of Cooperative Channels Explains the Maturation of Hair Cell's Mechanotransduction. Biophys J. 2019; 117(8): 1536-48.

PubMed Abstract | Publisher Full Text | Free Full Text |

Faculty Opinions Recommendation

70. Ashmore J: Cochlear outer hair cell motility. Physiol Rev. 2008; 88(1): 173-210. PubMed Abstract | Publisher Full Text

71. Frank G, Hemmert W, Gummer AW: Limiting dynamics of high-frequency electromechanical transduction of outer hair cells. Proc Natl Acad Sci U S A. 1999; 96(8): 4420-5.

PubMed Abstract | Publisher Full Text | Free Full Text

72. Santos-Sacchi J, Tan W: The Frequency Response of Outer Hair Cell Voltage-Dependent Motility Is Limited by Kinetics of Prestin. J Neurosci. 2018; 38(24): 5495-506

PubMed Abstract | Publisher Full Text | Free Full Text |

Faculty Opinions Recommendation

73. Santos-Sacchi J, Tan W: Voltage Does Not Drive Prestin (SLC26a5) ElectroMechanical Activity at High Frequencies Where Cochlear Amplification Is Best. iScience. 2019; 22: 392-9.

PubMed Abstract | Publisher Full Text | Free Full Text |

Faculty Opinions Recommendation

74. Gorbunov D, Sturlese M, Nies F, et al:: Molecular architecture and the structural basis for anion interaction in prestin and SLC26 transporters. Nat Commun. 2014; 5: 3622.

PubMed Abstract | Publisher Full Text | Free Full Text

75. Geertsma ER, Chang YN, Shaik FR, et al:: Structure of a prokaryotic fumarate transporter reveals the architecture of the SLC26 family. Nat Struct Mol Biol. 2015; 22(10): 803-8.

PubMed Abstract | Publisher Full Text

76. Chang YN, Jaumann EA, Reichel K, et al: Structural basis for functional interactions in dimers of SLC26 transporters. Nat Commun. 2019; 10(1): 2032. PubMed Abstract | Publisher Full Text | Free Full Text

77. Walter JD, Sawicka M, Dutzler R: Cryo-EM structures and functional characterization of murine SIc26a9 reveal mechanism of uncoupled chloride transport. eLife. 2019; 8: e46986. PubMed Abstract | Publisher Full Text | Free Full Text | Faculty Opinions Recommendation

78. Kalinec F, Holley MC, Iwasa $\mathrm{KH}$, et al.: A membrane-based force generation mechanism in auditory sensory cells. Proc Natl Acad Sci U S A. 1992; 89(18): 8671-5.

PubMed Abstract | Publisher Full Text | Free Full Text

79. Weber $\mathrm{T}$, Zimmermann $\mathrm{U}$, Winter $\mathrm{H}$, et al:: Thyroid hormone is a critical determinant for the regulation of the cochlear motor protein prestin. Proc Natl Acad Sci U S A. 2002; 99(5): 2901-6.

PubMed Abstract | Publisher Full Text | Free Full Text

80. Yamashita T, Hakizimana P, Wu S, et al:: Outer Hair Cell Lateral Wall Structure 
Constrains the Mobility of Plasma Membrane Proteins. PLoS Genet. 2015; 11(9): e1005500.

PubMed Abstract | Publisher Full Text | Free Full Text

81. Legendre K, Safieddine S, Küssel-Andermann $\mathrm{P}$, et al:: alphall-betaV spectrin bridges the plasma membrane and cortical lattice in the lateral wall of the auditory outer hair cells. J Cell Sci. 2008; 121(Pt 20): 3347-56. PubMed Abstract | Publisher Full Text

82. Cortese M, Papal S, Pisciottano F, et al.: Spectrin $\beta V$ adaptive mutations and changes in subcellular location correlate with emergence of hair cell electromotility in mammalians. Proc Natl Acad Sci U S A. 2017; 114(8): 2054-9. PubMed Abstract | Publisher Full Text | Free Full Text

83. Triffo WJ, Palsdottir H, Song J, et al:: 3D Ultrastructure of the Cochlear Outer Hair Cell Lateral Wall Revealed By Electron Tomography. Front Cell Neurosci. 2019; 13: 560.

PubMed Abstract | Publisher Full Text | Free Full Text | Faculty Opinions Recommendation

84. Takahashi S, Sun W, Zhou Y, et al.: Prestin Contributes to Membrane Compartmentalization and Is Required for Normal Innervation of Outer Hair Cells. Front Cell Neurosci. 2018; 12: 211. PubMed Abstract | Publisher Full Text | Free Full Text Faculty Opinions Recommendation

85. Kamar RI, Organ-Darling LE, Raphael RM: Membrane cholesterol strongly influences confined diffusion of prestin. Biophys J. 2012; 103(8): 1627-36. PubMed Abstract | Publisher Full Text | Free Full Text

86. Kharkovets $\mathrm{T}$, Dedek K, Maier $\mathrm{H}$, et al:: Mice with altered $\mathrm{KCNQ} 4 \mathrm{~K}^{+}$channels implicate sensory outer hair cells in human progressive deafness. $E M B O \mathrm{~J}$. 2006; 25(3): 642-52.

PubMed Abstract | Publisher Full Text | Free Full Text

87. Perez-Flores MC, Lee JH, Park S, et al:: Cooperativity of $K_{v} 7.4$ channels confers ultrafast electromechanical sensitivity and emergent properties in cochlear outer hair cells. Sci Adv. 2020; 6(15): eaba1104.

PubMed Abstract | Publisher Full Text | Free Full Text |

Faculty Opinions Recommendation

88. Lipovsek M, Im GJ, Franchini LF, et al:: Phylogenetic differences in calcium permeability of the auditory hair cell cholinergic nicotinic receptor. Proc Natl Acad Sci U S A. 2012; 109(11): 4308-13.

PubMed Abstract | Publisher Full Text | Free Full Text

89. Oliver D, Klöcker N, Schuck J, et al.: Gating of $\mathrm{Ca}^{2+}$-activated $\mathrm{K}^{+}$channels controls fast inhibitory synaptic transmission at auditory outer hair cells. Neuron. 2000; 26(3): 595-601.

PubMed Abstract | Publisher Full Text

90. Winter $\mathrm{H}$, Braig $\mathrm{C}$, Zimmermann $\mathrm{U}$, et al.: Thyroid hormone receptor alpha1 is a critical regulator for the expression of ion channels during final differentiation of outer hair cells. Histochem Cell Biol. 2007; 128(1): 65-75.

PubMed Abstract | Publisher Full Text

91. Wersinger E, McLean WJ, Fuchs PA, et al.: BK channels mediate cholinergic inhibition of high frequency cochlear hair cells. PLOS One. 2010; 5(11): e13836. PubMed Abstract | Publisher Full Text | Free Full Text

92. Maison SF, Pyott SJ, Meredith AL, et al.: Olivocochlear suppression of outer hair cells in vivo: Evidence for combined action of BK and SK2 channels throughout the cochlea. J Neurophysiol. 2013; 109(6): 1525-34. PubMed Abstract | Publisher Full Text | Free Full Text

93. D Du H, Ye C, Wu D, et al:: The Cation Channel TMEM63B Is an Osmosensor Required for Hearing. Cell Rep. 2020; 31(5): 107596. PubMed Abstract | Publisher Full Text | Faculty Opinions Recommendation

94. Cimerman J, Waldhaus J, Harasztosi C, et al:: Generation of somatic electromechanical force by outer hair cells may be influenced by prestinCASK interaction at the basal junction with the Deiter's cell. Histochem Cell Biol. 2013; 140(2): 119-35.

PubMed Abstract | Publisher Full Text

95. Dierich M, Altoè A, Koppelmann J, et al:: Optimized Tuning of Auditory Inne Hair Cells to Encode Complex Sound through Synergistic Activity of Six Independent $\mathbf{K}^{+}$Current Entities. Cell Rep. 2020; 32(1): 107869. PubMed Abstract | Publisher Full Text

96. Oliver D, Taberner AM, Thurm $\mathrm{H}$, et al.: The role of $\mathbf{B K}_{\mathrm{ca}}$ channels in electrical signal encoding in the mammalian auditory periphery. J Neurosci. 2006; 26(23) $6181-9$

PubMed Abstract | Publisher Full Text | Free Full Text

97. Pyott SJ, Meredith AL, Fodor AA, et al:: Cochlear function in mice lacking the $B K$ channel alpha, beta1, or beta4 subunits. J Biol Chem. 2007; 282(5): 3312-24. PubMed Abstract | Publisher Full Text

98. Oliver D, Knipper M, Derst C, et al: Resting Potential and Submembrane Calcium Concentration of Inner Hair Cells in the Isolated Mouse Cochlea Are Set by KCNQ-Type Potassium Channels. J Neurosci. 2003; 23(6): 2141-9. PubMed Abstract | Publisher Full Text | Free Full Text

99. Berkefeld $\mathrm{H}$, Fakler $\mathrm{B}$ : Ligand-gating by $\mathrm{Ca}^{2+}$ is rate limiting for physiological operation of BK channels. J Neurosci. 2013; 33(17): 7358-67. PubMed Abstract | Publisher Full Text | Free Full Text

100. Lang I, Jung M, Niemeyer BA, et al.: Expression of the LRRC52 $\gamma$ subunit
( $\gamma 2)$ may provide $\mathrm{Ca}^{2+-i n d e p e n d e n t ~ a c t i v a t i o n ~ o f ~} \mathrm{BK}$ currents in mouse inner hair cells. FASEB J. 2019; 33(11): 11721-34.

PubMed Abstract | Publisher Full Text | Faculty Opinions Recommendation

101. Lingle CJ, Martinez-Espinosa PL, Yang-Hood A, et al:: LRRC52 regulates BK channel function and localization in mouse cochlear inner hair cells. Proc Natl Acad Sci U S A. 2019; 116: 18397-403.

PubMed Abstract | Publisher Full Text | Faculty Opinions Recommendation

102. Thurm $\mathrm{H}$, Fakler $\mathrm{B}$, Oliver $\mathrm{D}$ : $\mathbf{C a}^{2+-i n d e p e n d e n t ~ a c t i v a t i o n ~ o f ~} \mathrm{BK}_{\mathrm{ca}}$ channels at negative potentials in mammalian inner hair cells. J Physiol. 2005; 569(Pt 1): $137-51$.

PubMed Abstract | Publisher Full Text | Free Full Text

103. Holt JC, Chatlani S, Lysakowski A, et al.: Quantal and nonquantal transmission in calyx-bearing fibers of the turtle posterior crista. J Neurophysiol. 2007; 98(3): 1083-101.

PubMed Abstract | Publisher Full Text | Free Full Text

104. Moser T, Grabner CP, Schmitz F: Sensory Processing at Ribbon Synapses in the Retina and the Cochlea. Physiol Rev. 2020; 100(1): 103-44. PubMed Abstract | Publisher Full Text

105. Chakrabarti R, Wichmann C: Nanomachinery Organizing Release at Neuronal and Ribbon Synapses. Int J Mol Sci. 2019; 20(9): 2147. PubMed Abstract | Publisher Full Text | Free Full Text | Faculty Opinions Recommendation

106. Johnson SL, Safieddine S, Mustapha M, et al.: Hair Cell Afferent Synapses: Function and Dysfunction. Cold Spring Harb Perspect Med. 2019; 9(12): a033175. PubMed Abstract | Publisher Full Text | Free Full Text | Faculty Opinions Recommendation

107. Pangrsic T, Vogl C: Balancing presynaptic release and endocytic membrane retrieval at hair cell ribbon synapses. FEBS Lett. 2018; 592(21): 3633-50.

PubMed Abstract | Publisher Full Text | Faculty Opinions Recommendation

108. Pangrsic T, Singer JH, Koschak A: Voltage-Gated Calcium Channels: Key Players in Sensory Coding in the Retina and the Inner Ear. Physiol Rev. 2018; 98(4): 2063-96.

PubMed Abstract | Publisher Full Text | Free Full Text | Faculty Opinions Recommendation

109. Moser T: Presynaptic Physiology of Cochlear Inner Hair Cells. in The Senses: A Comprehensive Reference (Academic Press Inc), 2020.

110. Jean $\mathrm{P}$, de la Lopez Morena DL, Michanski $\mathrm{S}$, et al:: The synaptic ribbon is critical for sound encoding at high rates and with temporal precision. eLife. 2018; 7: e29275.

PubMed Abstract | Publisher Full Text | Free Full Text | Faculty Opinions Recommendation

111. A Becker L, Schnee ME, Niwa M, et al:: The presynaptic ribbon maintains vesicle populations at the hair cell afferent fiber synapse. eLife. 2018; 7 : e30241.

PubMed Abstract | Publisher Full Text | Free Full Text |

Faculty Opinions Recommendation

112. Khimich $D$, Nouvian R, Pujol R, et al.: Hair cell synaptic ribbons are essential for synchronous auditory signalling. Nature. 2005; 434(7035): 889-94. PubMed Abstract | Publisher Full Text

113. Buran BN, Strenzke N, Neef A, et al:: Onset coding is degraded in auditory nerve fibers from mutant mice lacking synaptic ribbons. $J$ Neurosci. 2010 30(22): 7587-97.

PubMed Abstract | Publisher Full Text | Free Full Text

114. Frank T, Rutherford MA, Strenzke N, et al.: Bassoon and the synaptic ribbon organize $\mathrm{Ca}^{2+}$ channels and vesicles to add release sites and promote refilling. Neuron. 2010; 68(4): 724-38.

PubMed Abstract | Publisher Full Text | Free Full Text

115. Jing Z, Rutherford MA, Takago $\mathrm{H}$, et al:: Disruption of the presynaptic cytomatrix protein bassoon degrades ribbon anchorage, multiquantal release, and sound encoding at the hair cell afferent synapse. J Neurosci. 2013; 33(10): 4456-67. PubMed Abstract | Publisher Full Text | Free Full Text

116. Jung S, Maritzen T, Wichmann C, et al:: Disruption of adaptor protein $2 \mu$ (AP-2 $\mu$ ) in cochlear hair cells impairs vesicle reloading of synaptic release sites and hearing. EMBO J. 2015; 34(21): 2686-702. PubMed Abstract | Publisher Full Text | Free Full Text

117. Vogl C, Cooper BH, Neef J, et al:: Unconventional molecular regulation of synaptic vesicle replenishment in cochlear inner hair cells. J Cell Sci. 2015; 128(4): 638-44. PubMed Abstract | Publisher Full Text

118. Strenzke N, Chakrabarti R, Al-Moyed H, et al.: Hair cell synaptic dysfunction, auditory fatigue and thermal sensitivity in otoferlin lle515Thr mutants. $E M B O$ J. 2016; 35(23): 2519-35.

PubMed Abstract | Publisher Full Text | Free Full Text

119. Schnee ME, Santos-Sacchi J, Castellano-Muñoz M, et al:: Calcium-dependent synaptic vesicle trafficking underlies indefatigable release at the hair cell afferent fiber synapse. Neuron. 2011; 70(2): 326-38. PubMed Abstract | Publisher Full Text | Free Full Text 
120. Krinner S, Butola T, Jung S, et al.: RIM-Binding Protein 2 Promotes a Large Number of CaV1.3 $\mathrm{Ca}^{2+}$-Channels and Contributes to Fast Synaptic Vesicle Replenishment at Hair Cell Active Zones. Front Cell Neurosci. 2017; 11: 334. PubMed Abstract | Publisher Full Text | Free Full Text

121. Jung $\mathrm{S}$, Oshima-Takago $\mathrm{T}$, Chakrabarti R, et al:: Rab3-interacting molecules $2 \alpha$ and $2 \beta$ promote the abundance of voltage-gated CaV1.3 Ca2+ channels at hai cell active zones. Proc Natl Acad Sci U S A. 2015; 112(24): E3141-9. PubMed Abstract | Publisher Full Text | Free Full Text

122. Kroll J, Jaime Tobón LM, Vogl C, et al:: Endophilin-A regulates presynaptic $\mathrm{Ca}^{2+}$ influx and synaptic vesicle recycling in auditory hair cells. EMBO J.2019; 38(5): e100116.

PubMed Abstract | Publisher Full Text | Free Full Text

123. Kroll J, Özçete OD, Jung S, et al:: AP180 promotes release site clearance and clathrin-dependent vesicle reformation in mouse cochlear inner hair cells. J Cell Sci. 2020; 133(2): jcs236737.

PubMed Abstract | Publisher Full Text

124. Revelo NH, Kamin D, Truckenbrodt S, et al.: A new probe for super-resolution imaging of membranes elucidates trafficking pathways. J Cell Biol. 2014; 205(4): 591-606

PubMed Abstract | Publisher Full Text | Free Full Text

125. Kantardzhieva A, Liberman MC, Sewell WF, et al.: Quantitative analysis of ribbons, vesicles, and cisterns at the cat inner hair cell synapse: Correlations with spontaneous rate. J Comp Neurol. 2013; 521(14): 3260-71. PubMed Abstract | Publisher Full Text | Free Full Text

126. Oonn TL, Rutherford MA, Jing Z, et al:: Hair cells use active zones with different voltage dependence of $\mathrm{Ca}^{2+}$ influx to decompose sounds into complementary neural codes. Proc Natl Acad Sci U S A. 2016; 113(32): E4716-25. PubMed Abstract | Publisher Full Text | Free Full Text | Faculty Opinions Recommendation

127. Neef J, Urban NT, Ohn TL, et al:: Quantitative optical nanophysiology of $\mathrm{Ca}^{2+}$ signaling at inner hair cell active zones. Nat Commun. 2018; 9(1): 290. PubMed Abstract | Publisher Full Text | Free Full Text

128. Shrestha BR, Chia C, Wu L, et al.: Sensory Neuron Diversity in the Inner Ear Is Shaped by Activity. Cell. 2018; 174(5): 1229-1246.e17.

PubMed Abstract | Publisher Full Text | Free Full Text | Faculty Opinions Recommendation

129. A Sun S, Babola T, Pregernig G, et al: Hair Cell Mechanotransduction Regulates Spontaneous Activity and Spiral Ganglion Subtype Specification in the Auditory System. Cell. 2018; 174(5): 1247-1263.e15. PubMed Abstract | Publisher Full Text | Free Full Text | Faculty Opinions Recommendation

130. CPlatzer J, Engel J, Schrott-Fischer A, et al.: Congenital Deafness and Sinoatrial Node Dysfunction in Mice Lacking Class D L-Type $\mathrm{Ca}^{2+}$ Channels. Cell. 2000; 102(1): 89-97.

PubMed Abstract | Publisher Full Text | Faculty Opinions Recommendation

131. Dou $\mathrm{H}$, Vazquez $\mathrm{AE}$, Namkung $\mathrm{Y}$, et al.: Null mutation of alpha1D $\mathrm{Ca}^{2+}$ channe gene results in deafness but no vestibular defect in mice. JARO. 2004; 5(2): 215-26.

PubMed Abstract | Publisher Full Text | Free Full Text

132. Brandt A, Striessnig J, Moser T: Ca V 1.3 Channels Are Essential for Development and Presynaptic Activity of Cochlear Inner Hair Cells. J Neurosci. 2003; 23(34): 10832-40. PubMed Abstract | Publisher Full Text | Free Full Text

133. Scharinger A, Eckrich S, Vandael DH, et al:: Cell-type-specific tuning of Cav1.3 $\mathrm{Ca}\left({ }^{2+}\right)$-channels by a C-terminal automodulatory domain. Front Cell Neurosci. 2015; 9: 309.

PubMed Abstract | Publisher Full Text | Free Full Text

134. Fell B, Eckrich S, Blum K, et al:: $\boldsymbol{\alpha}_{2} \delta \mathbf{2}$ Controls the Function and Trans-Synaptic Coupling of Cav1.3 Channels in Mouse Inner Hair Cells and Is Essential for Normal Hearing. J Neurosci. 2016; 36(4): 11024-36. PubMed Abstract | Publisher Full Text | Free Full Text

135. Neef J, Gehrt A, Bulankina AV, et al.: The $\mathrm{Ca}^{2+}$ channel subunit beta2 regulates $\mathrm{Ca}^{2+}$ channel abundance and function in inner hair cells and is required for hearing. J Neurosci. 2009; 29(34): 10730-40. PubMed Abstract | Publisher Full Text | Free Full Text

136. Kuhn $S$, Knirsch $M$, Rüttiger $L$, et al.: Ba2+ currents in inner and outer hair cells of mice lacking the voltage-dependent $\mathrm{Ca} 2+$ channel subunits beta3 or beta4. Channels (Austin). 2009; 3(5): 366-76. PubMed Abstract | Publisher Full Text

137. Picher MM, Gehrt A, Meese S, et al:: $\mathrm{Ca}^{2+}$-binding protein $\mathbf{2}$ inhibits $\mathrm{Ca}^{2+}$-channe inactivation in mouse inner hair cells. Proc Natl Acad Sci U S A. 2017; 114(9): E1717-E1726. PubMed Abstract | Publisher Full Text | Free Full Text

138. C Yang T, Hu N, Pangršič T, et al.: Functions of CaBP1 and CaBP2 in the peripheral auditory system. Hear Res. 2018; 364: 48-58. PubMed Abstract | Publisher Full Text | Free Full Text | Faculty Opinions Recommendation

139. - Gregory FD, Bryan KE, Pangršič T, et al.: Harmonin inhibits presynaptic Cav1.3 $\mathrm{Ca}^{2+}$ channels in mouse inner hair cells. Nat Neurosci. 2011; 14(9):
1109-11

PubMed Abstract | Publisher Full Text | Free Full Text |

Faculty Opinions Recommendation

140. Picher MM, Oprişoreanu AM, Jung S, et al.: Rab Interacting Molecules 2 and 3 Directly Interact with the Pore-Forming $\mathrm{CaV} 1.3 \mathrm{Ca}^{2+}$ Channel Subunit and Promote Its Membrane Expression. Front Cell Neurosci. 2017; 11: 160 PubMed Abstract | Publisher Full Text | Free Full Text

141. Wong AB, Rutherford MA, Gabrielaitis M, et al:: Developmental refinement of hair cell synapses tightens the coupling of $\mathrm{Ca}^{2+}$ influx to exocytosis. EMBO J. 2014; 33(3): 247-64

PubMed Abstract | Publisher Full Text | Free Full Text

142. Schneider R, Hosy E, Kohl J, et al:: Mobility of calcium channels in the presynaptic membrane. Neuron. 2015; 86(3): 672-9. PubMed Abstract | Publisher Full Text

143. Zampini V, Johnson SL, Franz C, et al.: Elementary properties of $\mathrm{Ca}_{\mathbf{v}} \mathbf{1 . 3}$ $\mathrm{Ca}^{2+}$ channels expressed in mouse cochlear inner hair cells. $J$ Physiol. 2010; 588(Pt 1): 187-99.

PubMed Abstract | Publisher Full Text | Free Full Text

144. Zampini V, Johnson SL, Franz C, et al:: Burst activity and ultrafast activation kinetics of $\mathrm{CaV} 1.3 \mathrm{Ca}^{2+}$ channels support presynaptic activity in adult gerbil hair cell ribbon synapses. J Physiol. 2013; 591(16): 3811-20. PubMed Abstract | Publisher Full Text | Free Full Text | Faculty Opinions Recommendation

145. Zampini V, Johnson SL, Franz C, et al:: Fine Tuning of CaV1.3 $\mathrm{Ca}^{2+}$ channel properties in adult inner hair cells positioned in the most sensitive region of the Gerbil Cochlea. PLoS One. 2014; 9(11): e113750. PubMed Abstract | Publisher Full Text | Free Full Text

146. Zampini V, Valli $P$, Zucca G, et al:: Single-channel L-type $\mathrm{Ca}^{2+}$ currents in chicken embryo semicircular canal type I and type II hair cells. J Neurophysiol. 2006; 96(2): 602-12. PubMed Abstract | Publisher Full Text

147. Rodriguez-Contreras A, Yamoah EN, et al:: Direct measurement of singlechannel $\mathrm{Ca}^{2+}$ currents in bullfrog hair cells reveals two distinct channel subtypes. J Physiol. 2001; 534(Pt 3): 669-89. PubMed Abstract | Publisher Full Text | Free Full Text

148. Rodríguez-Contreras A, Yamoah EN, et al:: Effects of Permeant lon Concentrations on the Gating of L-Type $\mathrm{Ca}^{2+}$ Channels in Hair Cells. Biophys $\mathrm{J}$. 2003; 84(5): 3457-69. PubMed Abstract | Publisher Full Text | Free Full Text

149. Rodriguez-Contreras $\mathrm{A}$, Nonner $\mathrm{W}$, Yamoah $\mathrm{EN}: \mathrm{Ca}^{2+}$ transport properties and determinants of anomalous mole fraction effects of single voltage-gated $\mathrm{Ca}^{2+}$ channels in hair cells from bullfrog saccule. J Physiol. 2002; 538(Pt 3): 729-45. PubMed Abstract | Publisher Full Text | Free Full Text

150. Roberts WM: Localization of calcium signals by a mobile calcium buffer in frog saccular hair cells. J. Neurosci. 1994; 14(5 Pt 2): 3246-62 PubMed Abstract | Publisher Full Text | Free Full Text

151. Brandt $A$, Khimich $D$, Moser $T$ : Few $\mathrm{Ca}_{\mathrm{v}} \mathbf{1} \cdot \mathbf{3}$ channels regulate the exocytosis of a synaptic vesicle at the hair cell ribbon synapse. J Neurosci. 2005; 25(50): 11577-85.

PubMed Abstract | Publisher Full Text | Free Full Text

152. Moreno $\mathrm{CM}$, Dixon $\mathrm{RE}$, Tajada S, et al:: $\mathrm{Ca}\left({ }^{2+}\right)$ entry into neurons is facilitated by cooperative gating of clustered CaV1.3 channels. Elife. 2016; 5: e15744. PubMed Abstract | Publisher Full Text | Free Full Text

153. Frank $T$, Khimich $D$, Neef $A$, et al:: Mechanisms contributing to synaptic $\mathrm{Ca}^{2+}$ signals and their heterogeneity in hair cells. Proc Natl Acad Sci U S A. 2009; 106(11): 4483-8.

PubMed Abstract | Publisher Full Text | Free Full Text | Faculty Opinions Recommendation

154. Meyer AC, Frank T, Khimich D, et al:: Tuning of synapse number, structure and function in the cochlea. Nat Neurosci. 2009; 12(4): 444-53. PubMed Abstract | Publisher Full Text

155. Özçete ÖD, Moser T: A sensory cell diversifies its output by varying $\mathbf{C a}^{2+}$ influxrelease coupling among presynaptic active zones for wide range intensity coding. $E M B O J$. in press. Publisher Full Text

156. Vincent PFY, Cho S, Tertrais M, et al.: Clustered $\mathrm{Ca}^{2+}$ Channels Are Blocked by Synaptic Vesicle Proton Release at Mammalian Auditory Ribbon Synapses. Cell Rep. 2018; 25(12): 3451-3464.e3.

PubMed Abstract | Publisher Full Text | Free Full Text |

Faculty Opinions Recommendation

157. Kim DI, Kang M, Kim S, et al.: Molecular Basis of the Membrane Interaction of the $\beta 2 \mathrm{e}$ Subunit of Voltage-Gated $\mathrm{Ca}^{2+}$ Channels. Biophys J. 2015; 109(5): 922-35.

PubMed Abstract | Publisher Full Text | Free Full Text

158. Tian Y, Corkey RF, Yaney GC, et al.: Differential modulation of L-type calcium channel subunits by oleate. Am J Physiol Endocrinol Metab. 2008; 294(6): E1178-86.

PubMed Abstract | Publisher Full Text | Free Full Text

159. D Jean P, Özçete ÖD, Tarchini B, et al.: Intrinsic planar polarity mechanisms 
influence the position-dependent regulation of synapse properties in inner hair cells. Proc Natl Acad Sci U S A. 2019; 116(18): 9084-93. PubMed Abstract | Publisher Full Text | Free Full Text Faculty Opinions Recommendation

160. Sherrill HE, Jean P, Driver EC, et al.: Pou4f1 Defines a Subgroup of Type I Spira Ganglion Neurons and Is Necessary for Normal Inner Hair Cell Presynaptic $\mathrm{Ca}^{2+}$ Signaling. J Neurosci. 2019; 39(27): 5284-98. PubMed Abstract | Publisher Full Text | Free Full Text

161. Yin Y, Liberman LD, Maison SF, et al.: Olivocochlear innervation maintains the normal modiolar-pillar and habenular-cuticular gradients in cochlear synaptic morphology. J Assoc Res Otolaryngol. 2014; 15(4): 571-83. PubMed Abstract | Publisher Full Text | Free Full Text

162. Kiang NYS, Watanabe T, Thomas EC, et al.: Discharge Patterns of Single Fibers in the Cat's Auditory Nerve. (MIT Press). 1965. Reference Source

163. Liberman MC: Auditory-nerve response from cats raised in a low-noise chamber. J Acoust Soc Am. 1978; 63(2): 442-55 PubMed Abstract | Publisher Full Text

164. Young ED, Barta PE: Rate responses of auditory nerve fibers to tones in noise near masked threshold. J Acoust Soc Am. 1986; 79(2): 426-42. PubMed Abstract | Publisher Full Text

165. Winter IM, Palmer AR, Meddis R: The response of guinea pig auditory-nerve fibres with high spontaneous discharge rates to increments in intensity. Brain Res. 1993; 618(1): 167-70.

PubMed Abstract | Publisher Full Text

166. Taberner AM, Liberman MC: Response properties of single auditory nerve fibers in the mouse. J Neurophysiol. 2005; 93(1): 557-69. PubMed Abstract | Publisher Full Text

167. Petitpré $\mathrm{C}, \mathrm{Wu} \mathrm{H}$, Sharma A, et al.: Neuronal heterogeneity and stereotyped connectivity in the auditory afferent system. Nat Commun. 2018; 9(1): 3691. PubMed Abstract | Publisher Full Text | Free Full Text | Faculty Opinions Recommendation

168. Moglie MJ, Fuchs PA, Elgoyhen AB, et al:: Compartmentalization of antagonistic $\mathrm{Ca}^{2+}$ signals in developing cochlear hair cells. Proc Natl Acad SC U S A. 2018; 115(9): E2095-E2104.

PubMed Abstract | Publisher Full Text | Free Full Text | Faculty Opinions Recommendation

169. Várnai $P$, Gulyás $G$, Tóth $D J$, et al:: Quantifying lipid changes in various membrane compartments using lipid binding protein domains. Cell Calcium. 2017; 64: 72-82. PubMed Abstract | Publisher Full Text | Free Full Text

170. Idevall-Hagren O, de Camilli P: Detection and manipulation of phosphoinositides. Biochim Biophys Acta. 2015; 1851(6): 736-45. PubMed Abstract | Publisher Full Text | Free Full Text 